\title{
INDIA'S BILATERAL TRADE WITH CHINA- EMPIRICAL STUDY BASED ON TRADE INTENSITY INDEX \& TRADE RECIPROCITY INDEX
}

\begin{abstract}
Anand Shankar Paswan
Senior Research Fellow (SRF), Faculty of Commerce, Banaras Hindu University (BHU), India

\begin{tabular}{lllllll}
\hline Received: 28.12 .2020 & • & Accepted: 15.06.2021 & • & Published: 30.06.2021 & • Final Version: 30.06.2021
\end{tabular}

Abstract: This paper is an attempt to examine and compare the bilateral relationship between India and China. It analyses the trends in trade and the major composition of commodities being traded between India and China during the period (2008-2017). Annual Growth Rate (AGR), Combined Annual Growth Rate (CAGR), Trade Intensity Index (TII), and Trade Reciprocity Index (TRI) have been used in order to analyse the bilateral trade between India and China. The present study reveals that India imports 3 to 4 times more than it exports to China whereas overall trade between India and China also increased over the years specially in the area of import as compare to India's total trade to the world. However, the top ten commodities that have been dominating in India's trade with China are: Ores, Cotton, Copper and articles, Organic chemicals, Electrical machinery \& equipment, nuclear reactors, etc. Trade Intensity Index reveals there is serious unbalanced trade relationship between India and China from India's point of view and India need to take productive steps for minimising unbalanced trade balance. Whereas, TRI index also reveals that India is stepping towards unbalanced trade with China as the import indices keep on increasing in comparison to export indices and therefore, balance of trade results unfavourable which requires India to rethink and revamp its export and import policy.
\end{abstract}

Keywords: Exports; Imports; Trade Balance; Trade Intensity; India; China.

\section{Introduction}

India and China have always shared an inseparable relationship with each other whether it is cultural, political or economic relationship. Today India and China represent Asia's two largest and most dynamic economies and which has emerged as the new trend setter in the international market. India and China trade relationship is as old as ancient times from the period of Silk Roads (trade between Eastern part of the world to Western part of the world) to the present era. Trade between these nations started to escalate from 1950 when India was among the countable countries to end formal ties with China. In the year 1984, India and China entered into a trade agreement, which provided them the status of Most Favoured Nation (MFN). The year 1994, marked as the landmark year in the India-China economic relations, in this year a double taxation agreement was signed between India and China adding to this in the same year both the government authorities took necessary initiative to turn into dialogue partners in the Association of South Asian Nations (ASEAN). Whereas in 2003, Bangkok agreement was signed between India and China, in this agreement a major outcome was that India provided preferences on tariff for 217 products exported from India to China, further in the same year India and China entered into an agreement to initiate open border trade via the silk route. In 2008, India and China were the core and founding members of BRICS nations and it is said that BRICS nations have the potential to lead the global econ omy in the coming years, since BRICS represent more than 40 percent of the world population and BRICS countries accounts more than 20 percent of the world gross domestic product (GDP). Apart from 
these factors, India and China are the most populous countries in the world and also the fastest growing economies countries, both in Asia as well as in the world. In terms of GDP based on Purchasing Power Parity (PPP) India and China are within top three economy countries in the world, China is the world largest economy with worth noting US \$ 23.30 Trillion followed by United State US \$ 19.39 Trillion and the world's third largest economy is India with worth US \$ 9.45 Trillion in the year 2017. Whereas, in terms of GDP sorted by Nominal value India and China are in the top six economy countries of the world. The United State (US) shows its dominance by being the world's largest economy country in GDP (Nominal) notably worth US \$ 20.51 Trillion followed by China with worth US \$ 12.28 Trillion and India as the sixth largest economy with US \$ 2.6 Trillion. Statistical data are cluster clear to represent both developing nations are playing vital and dominating role in the world economy affair, specially China has left great impression in the international trade and investment flows.

Today, China is the world largest exporting nation while India's export has grown quite significantly in the recent years. Over more than two decades China has been dominating India's import and in the year 2013, China overtook UAE to become India's biggest trading partner whereas, India stands at 26th position on China's major exporting nations (2017) and overall, India is in the top ten trading destinations for China. U.S.A and U.A.E holds number one and second spot in India's exporting nations list while China stands at fourth position in export terms. Major commodities that were traded Ores, Cotton, Copper and articles, Organic chemicals, Electrical machinery \& equipment, nuclear reactors, Organic chemicals, Fertilisers etc. were based on 2-digit harmonized system code (HS Code). Whereas, on the levels of processing, India has witnessed a shift of raw materials goods to intermediate goods over the decade to China. In 2006, around 60 percent of India's exports to China were focused on raw materials however in 2016, share of raw materials fell to 25 percent, which in terms were to compensate for the rise in the share of intermediate goods from 34.5 percent in 2006 to 50 percent in the year 2016.

The current study aims to:

1. To evaluate trends and commodity composition of India -China bilateral trade.

2. To analyse India's Trade Intensities Index (TII) with China in the study period (2008 to 2017).

3. To investigate the nature of India's Balance of Trade with China and Trade Reciprocity Index (TRI)

\section{Review of literature}

In the study there have been several attempts to figure out the relationship between India and China bilateral trade; various indices were drawn for analysis purpose and to find out up to what extend countries trade with each other. The popular formula for calculating trade flows and patterns was defined as Trade Intensity (TI) was first popularised by Brown in 1949 and Kojima in 1962. TI examines the bilateral trade between two countries in relation to the total volume of world trade and its share to the world. Kim (2002) and Chandran (2010) who discussed and analysed bilateral trade intensity as well as revealed comparative advantage with India and ASEAN plus 3 (China, Japan and Korea) respectively. Some other analysis elaborating Indo-Chinese bilateral trade was conducted by Bhat, Guha and Paul (2006).

Bhattacharya et al. (2007) tried to analyze which country whether India or China gains and losses in their bilateral trade by using gravity model impact analysis. Bilateral trade was considered dependent variable (DV) and GNP of both India and China, per capita GNP, distance between both countries, tariff rate imposed by both countries at time of import and export, real effective exchange rate, country specific effect as independent variables (IVs) and the result suggest that the Free Trade Agreement (FTA) favours China in short run while it is unfavourable for India in short run, because of high tariff regime in India. In the long run, India has the potential to gain as higher than China once its tariff levels are brought down at par with China. 
Edmonds et al. (2010) study China's trade relationship with 182 nations during the period 1998 to 2005 by employing trade intensity and gravity model. The GMATI index indicates that China's trade intensity with ESA region were less intensive but in case of USC and EU its trade intensive is more, further adding to this GMATI index values show that China's trade intensity with African nations has increased over time.

Wani and Dhami (2013) in their paper "Indo-China Trade: Intensity and Potential for Future Trade" attempts to identify how the bilateral trade between India and China helps in growing their partnership for their mutual benefit in the coming time. The trends in the growth rate of China-India trade shows a huge potential focused on their political achievements.

Kumari and Malhotra (2014) in their paper "Trade-led growth in India and China: A comparative Analysis" tries to find out the impact of export-import growth on economic growth of both India and China. The study concludes that China performed better as compared to India, the reasons being the reforms speed, policy implementation and the nature of political governance.

Radha Raghuramapatruni (2014) examined the pattern of India- China trade relationship with special attention to service sector of both the nations by employing Trade Intensity Index (TII), Modified Trade Intensity Index (T'II) and Revealed Comparative Advantage Index ( RCA) finding suggest that India registered greater TII and T'II which represent India's higher dependent on China as a major export and import partner but for China the values are comparatively low which mean China depend more on other countries than India. While, RCA index for service sectors suggests that 12 items assessed for the purpose, 5 services categories are feasible for trade between both the countries.

Kumar Ravi (2018) in his paper "India's Foreign Trade with U.S.A. -A Study Based on Trade Intensity \& Reciprocity Index" tries to study the trade trend between India and U.S.A. The study concludes the bilateral trade between these two countries that India is moving towards unbalanced trade with the U.S.A.

\section{Methods Data and Discussion}

The research methodology which is being used to analyze India's trade with China (export and import) in the last Ten years is mainly based on the secondary data that has been collected from International Trade Centre, UNCOMTRADE and International Trade Statistics, World trade organization (WTO) etc. The methodologies used in this paper are Trade Intensities Index (TII) and Trade Reciprocity Index (TRI) along with the help of AGR and CAGR. Data series from 2008 to 2017 were selected for both direction and composition in order to enable a time comparison in the study period.

\subsection{Trade Intensity Index}

a. Export Intensity Index shows the value greater than 1 indicates that a particular country exports more to a particular country or region than would be expected its share in the world, while the value less than 1 indicates the opposite.

$$
\mathrm{XIIip}=\frac{X i p}{X i} / \frac{M p}{M w-M i}
$$

Where,

XIIip $=$ Export Intensity Index of country $i$ (India) with country $p$ (China)

Xip $=$ country $i$ (India) export to country $p$ (China)

$\mathrm{Xi}=$ country $i$ (India) export to the world $(w)$ 
$\mathrm{Mp}=$ country $p$ (China) import from the world $(w)$

$\mathrm{Mw}=$ total world import

$\mathrm{Mi}=$ country $i$ (India) import from the world $(w)$

b. Import Intensity Index shows the value greater than 1 indicates that a particular country imports more from a particular country or region than would be expected its share in the world, while the value less than 1 indicates the opposite.

$$
\text { MIIip }=\frac{\text { Mip }}{M i} / \frac{X p}{X w-X i}
$$

Where,

MIIip = Import Intensity Index of country $i$ (India) with country $p$ (China)

Mip $=$ country $i$ (India) import from country $p$ (China)

$\mathrm{Mi}=$ country $i$ (India) import from the world $(w)$

$\mathrm{Xp}=$ country $p$ (China) export to the world $(w)$

$\mathrm{Xw}=$ total world export

$\mathrm{Xi}=$ country $i$ (India) export to the world $(w)$

\section{Trade Reciprocity Index}

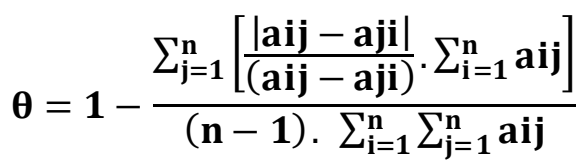

Where,

$\theta=$ Trade Reciprocity Index

$a i j=$ Export of country $i$ (India) to partner country $j$ (China)

$a j i=$ Export of country $j$ (China) to partner country $i$ (India)

$n=$ Total number of countries involve in the context of bilateral trade or regional.

\subsection{Trend in India- China Trade}

The table 1 shows the relationship between India and China for the study period (2008 to 2017). There is no second thought about China's contribution in India's overall trade specially when it comes to most reliable partner in terms of importing from global nations. In the study period there has been up and down in Annual Growth Rate (AGR) both at bilateral level trade with India and China as well as India's overall trade at global level. In the year 2010 bilateral trade between India and China took a leap and bounds and, in this year, AGR was $43 \%$ which the highest in the study period and followed by next best AGR in the immediate next year i.e., 2011 with $23 \%$. When we talk about India's overall trade at global level year 2011 is a benchmark year in terms of AGR for the study period in this year AGR were 34\%, whereas India's overall trade were US\$ 763886.04 Million in the same year. The second best in overall AGR was in the year 2010 with a AGR of $29 \%$ with total trade of US\$ 570437.88 Million. On the other hand, tortoise move at bilateral trade between India and China was in the year 2012, AGR were at its lowest with $-5 \%$ with a bilateral trade of US\$ 68869.77 Million and the next lowest was in the year 2016 with a AGR of $-3 \%$ with trade of US\$ 69399.18 Million. In similar situation India's overall global trade were at decline stage in the year 2015 with a negative AGR of $-16 \%$ while total trade was US\$ 655125.74 Million and second lowest was in the year 2009 with again a negative AGR of $-11 \%$ while total trade was US\$443166.59 Million. 
Meanwhile, Compound Annual Growth Rate (CAGR) both at bilateral trade between India and China and at overall India's trade shows a decent upward growth, in the study period CARG of India and China trade were $8 \%$ and at India's overall global trade it was $5 \%$. So, it is clear from the above table that bilateral trade between India and China had produced better results as compare to India's overall trade. When we consider China's contribution in India's total trade it has been in the range between $8 \%$ to $11 \%$ in the study period. Highest contribution of China in India's overall trade was in the year's 2015 , 2016 \& 2017 with its share of about 11\% in each year and lowest were in the year 2008 and 2013 with share of just $8 \%$ in India's overall trade.

Table 1. Trend between India China trade

(Values in US\$ Million)

\begin{tabular}{cccccc}
\hline Year & $\begin{array}{c}\text { Annual Growth } \\
\text { Inina trade }\end{array}$ & $\begin{array}{c}\text { Annual Growth } \\
\text { rate of Indo- China } \\
\text { Trade }\end{array}$ & $\begin{array}{c}\text { \% } \\
\text { India's } \\
\text { Total Trade }\end{array}$ & $\begin{array}{c}\text { of } \\
\text { rate of India's Total } \\
\text { Trade }\end{array}$ & $\begin{array}{c}\text { India's } \\
\text { Total Trade }\end{array}$ \\
\hline $\mathbf{2 0 0 8}$ & 41679.95 & & 497573.00 & & $8 \%$ \\
$\mathbf{2 0 0 9}$ & 40983.42 & $-2 \%$ & 443166.59 & $-11 \%$ & $9 \%$ \\
$\mathbf{2 0 1 0}$ & 58689.11 & $43 \%$ & 570437.88 & $29 \%$ & $10 \%$ \\
$\mathbf{2 0 1 1}$ & 72200.81 & $23 \%$ & 763886.04 & $34 \%$ & $9 \%$ \\
$\mathbf{2 0 1 2}$ & 68869.77 & $-5 \%$ & 778541.15 & $2 \%$ & $9 \%$ \\
$\mathbf{2 0 1 3}$ & 68052.27 & $-1 \%$ & 802656.96 & $3 \%$ & $8 \%$ \\
$\mathbf{2 0 1 4}$ & 71664.80 & $5 \%$ & 776914.11 & $-3 \%$ & $9 \%$ \\
$\mathbf{2 0 1 5}$ & 71181.01 & $-1 \%$ & 655125.74 & $-16 \%$ & $11 \%$ \\
$\mathbf{2 0 1 6}$ & 69399.18 & $-3 \%$ & 617031.70 & $-6 \%$ & $11 \%$ \\
$\mathbf{2 0 1 7}$ & 84463.57 & $22 \%$ & 739899.53 & $20 \%$ & $11 \%$ \\
& CAGR= & & & & \\
\hline
\end{tabular}

Source: International Trade Centre (ITC) calculations based on UN COMTRADE statistics

\subsection{India's Export to China and World}

China has always been an eminent trading partner for India in past two decade or so but due to some political instability and application of non-tariff barrier (NTBs) in recent years India's trade has been hampered specially India's export performance to China. China has always been in the top 5 exporting nation for India. There has been a roller coaster ride in India's export to China in the recent years, in the year 2010 India registered its highest export to China both in terms of AGR and overall export value with a AGR of $68.18 \%$ and export value of US\$ 17439.99 Million. After that India export to China has shown a downward slope maximum time in the year 2015 India's AGR to China were its all-time low with a negative AGR of $-28.72 \%$ with export value of just US\$ 9576.58 Million. The wheels of negative AGR was not only in just one year rather 5 times in the study period i.e., in the year 2011, 2012, 2014, 2015 and 2016 with negative AGR of $-4.14 \%,-11.89 \%,-18.17 \%,-28.72 \%$ and $6.90 \%$ respectively. Simultaneously, in the study period China's share in India's export has been in its lower side with a continuous downfall in its overall share percentage in India's export, India's ex port in the study period where never even in the two digit of its overall India's export percentage. India's all time high export to China was in the year 2010 with just $7.91 \%$ over India's total export to the world 
with export value of US\$17439.99 Million and the minimum contribution of China in India's export was in the year 2016 with a minimal sharing of just 3.42\% with export value of US\$ 8916.07 Million which was the lowest export value in terms of export to China. The ultimate outcome of rolling stone performance of India export to China was negligible CARG of just $2.40 \%$.

On the other hand, India's export performance at world level has been bit steady in terms of overall value exported. India's almost two-fold increase in its total export value from US\$176765.04 Million in year 2009 to US\$ 336611.39 Million in the year 2013. In terms of India's total trade to world AGR 2011 was the landmark year with a AGR of $36.78 \%$ followed by the year 2010 with a AGR of $24.69 \%$, in the same way India's total export were its all-time low in the year 2015 with AGR of $16.74 \%$ with total export value of US\$264381.00 Million followed by AGR of $-5.66 \%$ with total export of US\$ 317544.64 Million. India’s overall export with world was a mixed performance with a CAGR of 5.56\% which was more than twice as compare to India's export to China i.e., CAGR of just $2.40 \%$.

Table 2. India's Export to China and World

\begin{tabular}{|c|c|c|c|c|c|c|}
\hline Year & $\begin{array}{l}\text { Export to } \\
\text { China }\end{array}$ & $\begin{array}{l}\text { Annual Growth } \\
\text { Rate (AGR) }\end{array}$ & $\begin{array}{l}\text { Export } \\
\text { World } \\
\end{array}$ & to & $\begin{array}{l}\text { Annual Growth } \\
\text { Rate (AGR) }\end{array}$ & $\begin{array}{lr}\% \text { of total } \\
\text { export } \\
\text { China }\end{array}$ \\
\hline 2008 & 10093.93 & & 181860.90 & & & $5.55 \%$ \\
\hline 2009 & 10370.05 & $2.74 \%$ & 176765.04 & & $-2.80 \%$ & $5.87 \%$ \\
\hline 2010 & 17439.99 & $68.18 \%$ & 220408.50 & & $24.69 \%$ & $7.91 \%$ \\
\hline 2011 & 16717.79 & $-4.14 \%$ & 301483.25 & & $36.78 \%$ & $5.55 \%$ \\
\hline 2012 & 14729.32 & $-11.89 \%$ & 289564.77 & & $-3.95 \%$ & $5.09 \%$ \\
\hline 2013 & 16416.83 & $11.46 \%$ & 336611.39 & & $16.25 \%$ & $4.88 \%$ \\
\hline 2014 & 13434.25 & $-18.17 \%$ & 317544.64 & & $-5.66 \%$ & $4.23 \%$ \\
\hline 2015 & 9576.58 & $-28.72 \%$ & 264381.00 & & $-16.74 \%$ & $3.62 \%$ \\
\hline 2016 & 8916.07 & $-6.90 \%$ & 260326.91 & & $-1.53 \%$ & $3.42 \%$ \\
\hline \multirow[t]{2}{*}{2017} & 12492.39 & $40.11 \%$ & 295846.89 & & $13.64 \%$ & $4.22 \%$ \\
\hline & $\mathrm{CAGR}=2.40 \%$ & & $\mathrm{CAGR}=5.5$ & & & \\
\hline
\end{tabular}

Source: International Trade Centre (ITC) calculations based on UN COMTRADE statistics

\subsection{Top Ten Commodities India's export to China}

Top ten commodities which has been playing crucial role in India's trade have been drawn on average basis from the year 2008 to 2017 and accordingly rank has been assigned to respective commodities. Since, India has been facing unfavourable trade balance in the study period throughout the ten years. In India's bilateral trade with China product which are dominating the India's export to China are Ores, slag and ash, Cotton, Copper and articles, Organic chemicals, Mineral fuels, mineral 
oils etc. over the period of time there has been unstable pattern of export to China like HS Code 26 Ores, slag and ash has highest value in the year with US\$ 6347.29 Million and it reached to its all-time low in the year 2015 US\$ 435.13 Million which is about 15th time lower export, even though Ores, slag and ash holds the number one spot in India's export to China. Other next two best exporting products are HS Code 52 Cotton and HS Code 74 Copper and articles their export patterns has been changing over the past decade, in the year 2008 HS Code 52 Cotton were worth US\$ 779.6 Million and its was lowest in the year 2009 with value US\$ 618.34 Million and it almost jump up 8 folds in the year 2013 with value of US $\$ 4843.09$ Million which was highest in the study period for HS code 52 Cotton.

HS Code 29 and 27 Organic chemicals and Mineral fuels, mineral oils hold the number 4th and 5th position respectively in India's export to China. In the year 2017 Organic chemicals registered is highest export worth US\$1697.40 Million which was around 4 times higher than the year 2008 value US\$ 456.05 Million. On the other hand, Mineral fuels, mineral oils export has changed dramatically over the years, especially after the global crisis in 2008 and it impact directly in the very next year 2009 with its value all time low US\$ 54.57 Million but it recovers very shortly and in the year 2011 its value was US\$1618.73 Million which was highest in the study period. Subsequently, in the study period HS Code 72 and HS Code 85 Iron and steel and Electrical machinery and equipment holds the 9th and 10th position, Iron and steel were its all-time low export to China in the year 2015 with value US\$ 159.39 Million and highest in the 2010 with US\$ 739.79 Million. Electrical machinery and equipment were at the end position with 10th rank its value was its all-time low in the year 2008 with worth US\$100.03 Million and it increased more than 4.5 times in the year 2017 with value US $\$ 460.60$ Million 
Table 3. Top ten commodities exported to China

(value US\$ Million)

\begin{tabular}{|c|c|c|c|c|c|c|c|c|c|c|c|c|c|}
\hline \multirow[b]{2}{*}{$\begin{array}{l}\text { S.L } \\
\text { NO }\end{array}$} & \multirow{2}{*}{$\begin{array}{l}\text { Product } \\
\text { code }\end{array}$} & \multirow[b]{2}{*}{ Product label } & \multicolumn{11}{|c|}{ India's exports to China } \\
\hline & & & 2008 & 2009 & 2010 & 2011 & 2012 & 2013 & 2014 & 2015 & 2016 & 2017 & Average \\
\hline 1 & 26 & Ores, slag and ash & 5829.16 & 4716.19 & 6347.29 & 4295.27 & 2615.13 & 1742.64 & 782.13 & 435.13 & 1166.20 & 1507.83 & 2943.70 \\
\hline 2 & 152 & Cotton & 779.63 & 618.34 & 2106.89 & 2799.83 & 3613.27 & 4843.09 & 2808.94 & 1985.26 & 1263.29 & 1147.60 & 2196.61 \\
\hline 3 & '74 & Copper and articles & 177.66 & 410.74 & 3629.69 & 1870.38 & 2194.89 & 1959.04 & 2104.76 & 1265.60 & 640.49 & 1379.97 & 1563.32 \\
\hline 4 & 29 & Organic chemicals & 456.05 & 456.62 & 757.98 & 860.63 & 1022.93 & 1046.73 & 956.72 & 868.32 & 785.59 & 1697.40 & 890.90 \\
\hline 5 & '27 & $\begin{array}{l}\text { Mineral fuels, mineral } \\
\text { oils }\end{array}$ & 154.29 & 54.57 & 372.09 & 1618.73 & 341.55 & 739.68 & 1605.47 & 601.96 & 699.97 & 1017.80 & 720.61 \\
\hline 6 & 25 & $\begin{array}{l}\text { Salt; sulphur; earths and } \\
\text { stone; plastering } \\
\text { materials, lime and } \\
\text { cement }\end{array}$ & 294.17 & 256.06 & 313.08 & 474.78 & 573.85 & 708.52 & 659.89 & 565.92 & 511.72 & 651.03 & 500.90 \\
\hline 7 & '84 & $\begin{array}{l}\text { Machinery, mechanical } \\
\text { appliances, nuclear } \\
\text { reactors }\end{array}$ & 208.09 & 340.32 & 280.78 & 373.24 & 402.91 & 508.16 & 523.01 & 474.88 & 465.95 & 665.83 & 424.32 \\
\hline 8 & '39 & $\begin{array}{l}\text { Plastics and articles } \\
\text { thereof }\end{array}$ & 165.97 & 203.79 & 370.69 & 618.10 & 608.03 & 687.61 & 405.53 & 318.72 & 267.24 & 426.44 & 407.21 \\
\hline 9 & 72 & Iron and steel & 205.60 & 420.60 & 739.79 & 645.34 & 328.22 & 373.03 & 163.41 & 159.39 & 221.97 & 394.83 & 365.22 \\
\hline 10 & '85 & $\begin{array}{l}\text { Electrical machinery } \\
\text { and equipment }\end{array}$ & 100.03 & 249.33 & 206.27 & 327.28 & 250.87 & 303.65 & 311.49 & 247.42 & 389.94 & 460.60 & 284.69 \\
\hline
\end{tabular}

*ranks a re assigned on average basis for the period 2008 to 2017.

Source: International Tra de Centre (ITC) calculations based on UNCOMTRADE statistics 


\subsection{India's Import from China and world}

For the last decade China has been the number one India's importing partner, China's trend of import to India has always been on rise except for a few years with minor negative AGR. China's share in India's total import has always in between $10 \%$ to $17 \%$ in the study period, China took more than twofold in terms of import value to India from US\$30613.37 Million in the year 2009 to US\$ 71971.17 Million in the year 2017. When we consider AGR as the base 2010 year was registered as the highest AGR with 34.74\% and with import value of worth US\$41249.12 Million and with slight difference in the immediate next year i.e. 2011 with AGR of $34.51 \%$ and import value US\$ 55483.03 Million. Simultaneously, on the darker side of AGR year 2013 shows highest negative AGR with $-4.63 \%$ with import value US \$ 51635.44 Million and followed by year 2009 with AGR of $-3.08 \%$ with import worth US\$ 30613.37 Million. One of the major reasons behind fall down in import value was due to the global crisis in 2008 which directly affected the trade volume (both in import \& export) which is cluster clear in 2008 and 2009 both in terms of bilateral trade between India and China as well as a global level import by India. As India's import from world was at its minimum in the year 2008 and 2009 with import value of US\$315712.11 Million and US\$266401.55 Million respective which was lowest in the study period. In 2010 and 2011 imports from the world started recovering with total trade of worth value US\$ 350029.39Million and US\$ 462402.79 Million respectively with AGR $31.39 \%$ in 2010 and AGR 32.10\%. On the parallel China has always been dominating India market over more than two decades, China share in India's import was highest in the year 2016 with $16.96 \%$ share and the lowest in the year 2008 with China share of $10.00 \%$ in India's import. Over the years China has not been below the two digit share in India's import with adverse situation China has maintain its position in India which is clearly seen in terms of overall CAGR, China CAGR in India's import is 9.58\% which is 2.4 times higher than that of India's CAGR from the world import, as India's import from world with CAGR of just $4.00 \%$.

Table 4. Trends in India's import from China

(US\$ Million)

\begin{tabular}{lllcll}
\hline Year & $\begin{array}{c}\text { Importfrom } \\
\text { China }\end{array}$ & $\begin{array}{c}\text { Annual Growth } \\
\text { Rate (AGR) }\end{array}$ & $\begin{array}{c}\text { Import from } \\
\text { World }\end{array}$ & $\begin{array}{c}\text { Annual Growth } \\
\text { Rate (AGR) }\end{array}$ & $\begin{array}{c}\text { \% of total Import } \\
\text { from China }\end{array}$ \\
\hline $\mathbf{2 0 0 8}$ & 31586.02 & & 315712.11 & & $10.00 \%$ \\
$\mathbf{2 0 0 9}$ & 30613.37 & $-3.08 \%$ & 266401.55 & $-15.62 \%$ & $11.49 \%$ \\
$\mathbf{2 0 1 0}$ & 41249.12 & $34.74 \%$ & 350029.39 & $31.39 \%$ & $11.78 \%$ \\
$\mathbf{2 0 1 1}$ & 55483.03 & $34.51 \%$ & 462402.79 & $32.10 \%$ & $12.00 \%$ \\
$\mathbf{2 0 1 2}$ & 54140.46 & $-2.42 \%$ & 488976.38 & $5.75 \%$ & $11.07 \%$ \\
$\mathbf{2 0 1 3}$ & 51635.44 & $-4.63 \%$ & 466045.57 & $-4.69 \%$ & $11.08 \%$ \\
$\mathbf{2 0 1 4}$ & 58230.55 & $12.77 \%$ & 459369.46 & $-1.43 \%$ & $12.68 \%$ \\
$\mathbf{2 0 1 5}$ & 61604.43 & $5.79 \%$ & 390744.73 & $-14.94 \%$ & $15.77 \%$ \\
$\mathbf{2 0 1 6}$ & 60483.10 & $-1.82 \%$ & 356704.79 & $-8.71 \%$ & $16.96 \%$
\end{tabular}




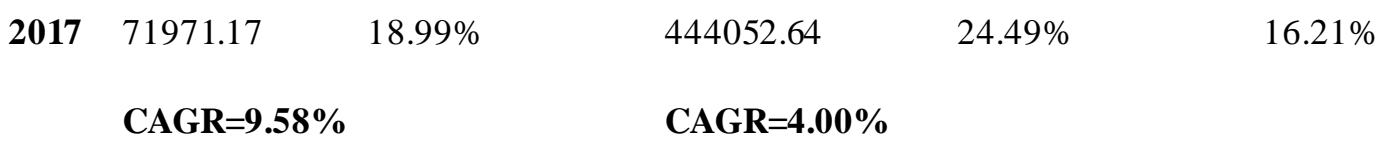

Source: International Trade Centre (ITC) calculations based on UN COMTRADE statistics

\subsection{Top ten commodities import from China}

Table: 5 examine the top ten commodities imported from China. As import from China has always been an important part of India's trade with China. In the study period India has always been in deficit trade balance with China. India's import from China has always been in the two digits as compare to import from world, it's always been in between $10 \%$ to $17 \%$ of total import from world. Major commodities which has been dominating India's import from China are Electrical machinery and equipment, Machinery, mechanical appliances, nuclear reactors, Organic chemicals, Fertilisers, Iron and steel etc. HS Code 85 Electrical machinery and equipment was most imported commodities over the years and it has been changing over the time, in the year 2008 it was at its lowest with worth US\$ 8477.32 Million and its jumps up to 3.5 times in the year 2017 with value US\$27539.00 Million. Machinery, mechanical appliances, nuclear reactors were the most second most imported commodity from China with average value US\$ 9286.11 Million with lowest imported value in the year 2009 with imported volume US\$ 5880.98 Million and highest in the year 2017 with volume US\$ 12808.12 Million. 3rd and 4th best commodities which were imported from China were HS Code 29 and HS Code 31 Organic chemicals and Fertilisers respectively, in the 2009 Organic chemicals registered at is lowest worth US\$2775.76 Million and highest in the year 2017 with value US\$ 6570.78 Million and overall average value was US\$ 4791.15 Million followed by Fertilisers its highest value was in the year 2015 with import value of US\$ 3530.38 Million and lowest in the 2009 with value US\$ 469.48 Million. Simultaneously, is the study period 5th to 8th position commodities were HS Code 72 Iron and steel, HS Code 39 Plastics and articles, HS Code 73 Articles of iron or steel, and HS Code 90 Optical, photographic, cinematographic respectively. There highest import was in the range between US\$ 2500 Million to US\$ 1400 Million and lowest was in the range between US\$900 Million to US\$ 600 Million. On the other hand, 9th and 10th position was hold by HS Code 87 Vehicles other than railway or tramway rolling stock and HS Code 89 Ships, boats and floating structures. Highest import value of Vehicles other than railway or tramway rolling stock was US\$1319.30 Million in the year 2017 and lowest in the year 2009 with value US\$ 403.06 Million followed by 10th position Ships, boats and floating structures its highest value was in the year 2016 with value US\$ 1778.82 Million and lowest worth US\$213.29 Million in the year 2008 . 
Table 5. Top ten commodities Imported from China

(US\$ Million)

\begin{tabular}{|c|c|c|c|c|c|c|c|c|c|c|c|c|c|}
\hline \multirow[b]{2}{*}{$\begin{array}{l}\text { S.L } \\
\text { NO }\end{array}$} & \multirow{2}{*}{$\begin{array}{l}\text { H.S } \\
\text { code }\end{array}$} & \multirow[b]{2}{*}{ Product label } & \multicolumn{11}{|c|}{ India's imports from China } \\
\hline & & & 2008 & 2009 & 2010 & 2011 & 2012 & 2013 & 2014 & 2015 & 2016 & 2017 & Average \\
\hline 1 & '85 & Electrical machinery and equipment & 8477.32 & 10503.97 & 11274.11 & 13240.76 & 13114.01 & 14444.09 & 15977.00 & 19352.57 & 20871.19 & 27539.00 & 15479.40 \\
\hline 2 & '84 & $\begin{array}{l}\text { Machinery, mechanical appliances, } \\
\text { nuclear reactors }\end{array}$ & 6075.82 & 5880.98 & 7219.61 & 9791.62 & 10234.00 & 9768.29 & 9770.04 & 10584.54 & 10728.06 & 12808.12 & 9286.11 \\
\hline 3 & 29 & Organic chemicals & 2857.48 & 2775.76 & 3741.42 & 4080.43 & 4622.13 & 5259.01 & 6256.63 & 6162.35 & 5585.55 & 6570.78 & 4791.15 \\
\hline 4 & 31 & Fertilisers & 1125.97 & 469.48 & 1367.04 & 2727.04 & 2689.23 & 2212.00 & 2706.59 & 3530.38 & 1537.84 & 1113.72 & 1947.93 \\
\hline 5 & 72 & Iron and steel & 1741.57 & 693.55 & 2142.63 & 1993.60 & 1694.32 & 1044.06 & 2262.42 & 2416.39 & 1647.55 & 1633.20 & 1726.93 \\
\hline 6 & '39 & Plastics and articles & 570.41 & 479.27 & 783.29 & 1212.40 & 1272.00 & 1255.89 & 1716.98 & 1613.03 & 1837.34 & 2137.75 & 1287.84 \\
\hline 7 & 73 & Articles of iron or steel & 1146.49 & 876.04 & 1054.75 & 1452.81 & 1420.28 & 1345.43 & 1412.46 & 1215.08 & 1202.38 & 1375.82 & 1250.15 \\
\hline 8 & '90 & Optical, photographic, cinematographic & 330.36 & 627.14 & 641.74 & 921.06 & 1096.21 & 1046.61 & 1189.55 & 1252.18 & 1312.46 & 1598.75 & 1001.61 \\
\hline 9 & '87 & $\begin{array}{l}\text { Vehicles other than railway or tramway } \\
\text { rolling stock }\end{array}$ & 452.88 & 403.06 & 685.28 & 1008.63 & 1034.88 & 1002.10 & 1135.68 & 1112.97 & 1140.38 & 1319.30 & 929.52 \\
\hline 10 & '89 & Ships, boats and floating structures & 213.29 & 302.43 & 1086.40 & 1436.33 & 694.48 & 738.37 & 1283.24 & 877.55 & 1778.82 & 827.69 & 923.86 \\
\hline
\end{tabular}

*rank was assigned on average basis for the period 2008 to 2017.

Source: International Trade Centre (ITC) calculations based on UN COMTRADE statistics 


\subsection{India's trade intensity with China}

India's trade intensity both import and export by China has been computed by using the data from International Trade Centre, data based on UNCOMTRADE for the study period 2008 to 2017 and presented in a tabulation form. It is clear from the table that export intensity to China has never been up to the standard of import from the China, export intensity never touched the 1 mark. In 2008 export intensity was 0.79 and in 2009 it was 0.72 and highest in the year 2010 with 0.85 after 2010 export intensity never recovered and started to shrink every year. In the year 2011 it was 0.57 and in 2012 is was recorded at 0.50 , export intensity down fall didn't stop here in subsequent years it fell more in 2013 it was 0.46 and in 2014 it was 0.40 . China share in India's export also started to downfall in the study period its highest share in India's export was in the year 2010 with $7.91 \%$ share in India's total export and lowest in the year 2016 with $3.42 \%$ share which was lowest in terms of export intensity also with 0.34 . It has started showing an upward trend in 2017 with trade intensity 0.40 hope this will continue for a longer period of time. Thus, we can conclude that India needs to increase their export to China in coming years so it can minimise its deficit trade and maintain a fair-trade balance.

On the other hand, trade balance between India and China has always been unfavourable for India i.e., India imports more than exports which shadow can easily be seen over import intensity index in the study period import intensity has always been above 1 except in some years but even though it was close to 1 . In the year 2008 import intensity was 1.10 followed by 1.16 in the immediate next year, in the subsequent years import intensity was quite stable between the range 1.26 to 0.93 . In the year 2013 it was at its lowest point 0.93 comparing it with export intensity it was not equivalent to import lowest level (export intensity highest 0.86 and import intensity lowest 0.93 ). So, as an overall trade intensity index we can clearly figure out the trade imbalance between India and China which is unfavourable as far as India's trade in concern, a positive potential exists from India's point to increase its overall share in China's market.

Table 6. India's Trade Intensity Index with China

\begin{tabular}{lll}
\hline Year & Export Intensity & Import Intensity \\
\hline $\mathbf{2 0 0 8}$ & 0.79 & 1.10 \\
$\mathbf{2 0 0 9}$ & 0.72 & 1.16 \\
$\mathbf{2 0 1 0}$ & 0.85 & 1.11 \\
$\mathbf{2 0 1 1}$ & 0.57 & 1.12 \\
$\mathbf{2 0 1 2}$ & 0.50 & 0.98 \\
$\mathbf{2 0 1 3}$ & 0.46 & 0.93 \\
$\mathbf{2 0 1 4}$ & 0.40 & 1.00 \\
$\mathbf{2 0 1 5}$ & 0.35 & 1.12 \\
$\mathbf{2 0 1 6}$ & 0.34 & 1.26 \\
$\mathbf{2 0 1 7}$ & 0.40 & 1.24 \\
\hline
\end{tabular}

Source: Author's own calculation

\subsection{India - China Trade Balance}

An economy is said to be favourable when its trade balance with the trading country find to at minimum imbalance, both situation is not beneficial whether there is high export and low import or vice-versa. India has been a victim of great trade imbalance with china not even in a single year trade was favour or surplus for India's point of view in the study period. Rather the scenario was that trade 
deficit started to increase almost every year, in 2008 deficit trade balance was US\$21492.10 Million and its continuously increases each year and ultimately its reached its highest level in the year 2017 with US\$ 59478.78 Million which is a major concern for India's trade with China which need to be reduced for flourishing India's economy.

Table 7.India - China Balance of Trade

\begin{tabular}{llll}
\hline Year & India's Export to China & India's Import from China & (Trade balance) \\
\hline $\mathbf{2 0 0 8}$ & 10093.93 & 31586.02 & -21492.10 \\
$\mathbf{2 0 0 9}$ & 10370.05 & 30613.37 & -20243.32 \\
$\mathbf{2 0 1 0}$ & 17439.99 & 41249.12 & -23809.13 \\
$\mathbf{2 0 1 1}$ & 16717.79 & 55483.03 & -38765.24 \\
$\mathbf{2 0 1 2}$ & 14729.32 & 54140.46 & -39411.14 \\
$\mathbf{2 0 1 3}$ & 16416.83 & 51635.44 & -35218.62 \\
$\mathbf{2 0 1 4}$ & 13434.25 & 58230.55 & -44796.30 \\
$\mathbf{2 0 1 5}$ & 9576.58 & 61604.43 & -52027.85 \\
$\mathbf{2 0 1 6}$ & 8916.07 & 60483.10 & -51567.03 \\
$\mathbf{2 0 1 7}$ & 12492.39 & 71971.17 & -59478.78 \\
\hline
\end{tabular}

Source: International Trade Centre (ITC) calculations based on UN COMTRADE statistics

This table represent the India's trade reciprocity index with China. In a nut-cell it is cluster clear reciprocity index is totally against India, it is never near to unity perhaps it's very above that mark which shows adverse situation for India. In the year 2008 reciprocity index was 1.52 and its fall down a little bit in the subsequent year in 2009 it was 1.49 and in 2010 it was 1.41 respectively, after 2010 reciprocity index increased almost every year which is not in favour of India. In the year 2016 reciprocity index was at its highest 1.74 which illustrate in this year the difference between India's export and import was highest in terms of reciprocity. However, a trade reciprocity index closer to zero means India are exporting very much as compare to import in this case it in also unbalance trade practice with China. But in our case a trade reciprocity index is very much above the 1 -unit mark which is also unbalanced trade practice for India i.e., we are importing very much as compare to exporting to China. 
Table 8. Trade Reciprocity Index between India and China

\begin{tabular}{llll}
\hline Year & India's Export to China & India's Import from China & Reciprocity Index \\
\hline $\mathbf{2 0 0 8}$ & 10093.93 & 31586.02 & 1.52 \\
$\mathbf{2 0 0 9}$ & 10370.05 & 30613.37 & 1.41 \\
$\mathbf{2 0 1 0}$ & 17439.99 & 41249.12 & 1.54 \\
$\mathbf{2 0 1 1}$ & 16717.79 & 55483.03 & 1.57 \\
$\mathbf{2 0 1 2}$ & 14729.32 & 54140.46 & 1.52 \\
$\mathbf{2 0 1 3}$ & 16416.83 & 51635.44 & 1.63 \\
$\mathbf{2 0 1 4}$ & 13434.25 & 58230.55 & 1.73 \\
$\mathbf{2 0 1 5}$ & 9576.58 & 61604.43 & 1.74 \\
$\mathbf{2 0 1 6}$ & 8916.07 & 60483.10 & 1.70 \\
\hline $\mathbf{2 0 1 7}$ & 12492.39 & 71971.17 & \\
\hline
\end{tabular}

Source: International Trade Centre (ITC) calculations based on UN COMTRADE statistics

\section{Conclusion}

It has been widely accepted that an increase in trade leads to deeper economic integration and assists in sustaining economic growth both at bilateral, regional as well as at the global economy and in this context, both India and China emerging countries have made a significant contribution to world trade. The volume of trade, GDP, Per capita income, population, employment, amicable cultural, stability in political condition etc. justifies the importance of these two nations at world level. The article examined trade relationship between India and China, elaborating the major factors that are responsible for fruitful and strong trade.

By using various qualitative and quantitative techniques, this paper observed lots of compelling results. Based on the first objective, the study finds that India is having unbalanced trade over all the study period and India imports around 4 times than its export to China. India's trade with China has much more flourished as compare to India's overall trade with the world, India china trade CAGR was $8 \%$ whereas India overall trade with world CAGR lies to only $5 \%$ in the same study period. On the other hand, India's export to China has declined almost every year India's export to China CAGR was just $2.40 \%$ while India's overall export to world CAGR was $5.56 \%$ which is more than two times that is the major concern from India's perspective. On the same note, India import has taken a leap in the study period India's import from China CAGR was 9.58\% which is 2.4 times higher that India overall import CAGR with the world which was $4.00 \%$, make a note part is that China's share in India overall import from world is between the range of $10 \%$ to $17 \%$ which leads China as the number one trading partner for India in terms of import. Result support the finding of (kumar ravi, 2018). India is moving towards unbalanced trade with China i.e., more imports than exports and it also support the finding of (Bhattacharya et al. 2007) unfavourable trade for India in the short run. 
Top ten commodities exported were Ores, slag and ash, Cotton, Copper and articles, Organic chemicals, Mineral fuels, mineral oils, Salt; sulphur, Machinery, mechanical appliances, Plastics and articles, Iron and steel and Electrical machinery and equipment which were in the range of average US\$ 2943.70 Million to US\$ 284.69 Million and rank was assigned on average basis for the period 2008 to 2017. Whereas Top ten commodities imported were Electrical machinery and equipment, Machinery, mechanical appliances, nuclear reactors, Organic chemicals, Fertilisers, Iron and steel, Plastics and articles, Articles of iron or steel, Optical, photographic, cinematographic, Vehicles other than railway or tramway rolling stock and Ships, boats and floating structures which were been imported in the range on average basis US\$15479.40 Million to US\$ 923.86 Million and rank was assigned on average basis for the period 2008 to 2017.

For second objective, the study attempted to test the India's trade intensity with China and it was found that India's export intensity is very low and declined almost every year from export intensity 0.78 to 0.34 while the major fact is that not even in the single year export intensity reached to unity level of 1 while import intensity was always above unity level in every year except in the year 2012 and 2013 its reached its height from 0.93 to 1.26 which is unfavourable from India's point of view and it need to be controlled up to some extent for favourable trade balance between both countries. Result support the finding of (Radha Raghuramapatruni, 2014)

For the third objective India - China Balance of Trade and Trade Reciprocity Index between India and China were taken into consideration as results elaborate that not even once in the study period India has a surplus trade balance rather almost every year the difference of deficit balance for India increased. Earlier in 2008 trade deficit balance was US \$ -21492.10 Million and it reached its highest level in the year 2017 with US \$ -59478.78 Million. Simultaneously, Trade Reciprocity Index (TRI) indicates that India is very much in unbalanced trade with China as indices increased on a continuous basis during the study period.

This study suggests that India needs to examine its export-import(EXIM) policies so that sky hiking trade unbalance specially from import prospective must be controlled as far as possible which will directly or indirectly will assist in India sustainable economy development and improving its trade relationship with China.

\section{References}

[1] Ayyub Salahuddin Indo-China trade relations: present trends and future prospects "China'Economy Relations", economy watch, http://economy watch.com/international-economic relations accessed on 15 July 2013

[2] Dr. Joginder Singh, M. (2014). A Comparative Study of India-China Bilateral Trade. International Joumal of Commerce, Bu siness and Management (IJCBM), 269-279.

[3] India China Trade relations, http://business.mapsofindia.com/traderelations/India-china, accessed on 15 july 2013.

[4] Neill. O.Jim Building BetterGlobalEconomic BRICs

[5] Paswan, A. S. (2018). India's Export Performance with BRICS Nations. Jo urnal of Emerging Technologies and Innovative Research , 304-310.

[6] Prof. Mathur Sajal and Dasgupta Meghna, "BRICS Trade Policies, Institutions and Areas for Deepening Cooperation's"Centre for WTO Studies, New Delhi, 2013

[7] Prof.Sajal Ma thur,MeghnaDasgupta. (2013). BRICS Tra de Policies, Institutions and Areas for Deepening Cooperation's. New Delhi: Centre for WTO Studies 
[8] Panda Rajesh * et al. A Study of Bila teral Trade Flows of China and India

[9] Patrick Blagrave et al. The implications ofChina's slowdown for international tra de

[10] Sushil Kumar bhadu, Garima pant, 'impact of WTO on bila teral trade between India and china',march 4, 2011, working paper series, a vailable athttp://papers.ssm.com/sol3/papers.cfm?abstractid=1859775, a ccessed on 27 July 2013.

[11] Swaran Singh, "China-India Bilateral trade: strong fundamentals Bright future,"http//chinaprespectives.revues.org/2853, a ccessed on 25 July 2013

[12] "World Economic Outlook". IMF. April 2013. Retrieved 17 April 2013.

[13] WTO, India and China http://www.authorstream.com/Presentation/rejaumeister-890580-wto-india-china, a ccessed on 27 July 2013. 